\title{
Quality in Museums as a Way to Increase Sustainability
}

\author{
Izabela Luiza Pop ${ }^{1}$, Anca Borza ${ }^{1}$
}

\begin{abstract}
:
Due to the high accent put on sustainable development of communities and on the role played by cultural organisations in this development process, this research starts from the hypothesis that quality may represent a path through which museums can achieve a higher level of sustainability. This hypothesis was tested through semi-structured interviews with experts from museums. The qualitative research showed that museums sustainability has to be measured through quantitative indicators but also through some quality-related indicators. Despite the fact that all experts pointed out a connection between sustainability measurement and quality, they argued that very few Romanian museums are carrying out such studies. Often, museums see quality measurement as something expensive, and thus unaffordable. Based on these facts, the second part of the paper seeks to highlight that quality is a much simpler tool than it is considered and museums can use this tool for improving their sustainability. Thus, the concept of museum quality is clarified by presenting the factors influencing it and some practical models which can be used by museums for measuring quality. By combining empirical and theoretical research, this paper may be of interest for other scholars studying museums sustainability and quality, but also for people working in museums.
\end{abstract}

Keywords: museum quality; sustainability; development; improvement; SERVQUAL; HISTOQUAL JEL classification: M10; Q01;

\section{Introduction}

Jackson (1988), one of the first specialists to study the quality of museum products and services, listed quality among the factors that influence the museum cost function. There are in the literature two approaches to how museum quality should be defined and measured (Negri et al., 2009). Very many researchers define quality depending on the clients' requirements. This type of quality is defined as "the public quality of a museum" (Negri et al., 2009). According to this view, a quality service is any service that satisfies the consumers' needs, wishes and expectations and offers the consumers a fulfilling experience (Radder et al., 2011: 318). The public quality can also be defined by the method used to measure it, as the difference between the clients' expectations and their perceptions of the services provided by a museum (Maher et al., 2011). The second approach defines and measures museum quality from a professional point of view as dependant on the importance, the value and the conservation of the collections held by that museum, as well as the scientific research carried out upon these collections (Pachucki, 2012). Thus, a distinction between the professional quality and the public quality of a museum arises. The two types of quality often seem to be in a conflict particularly since the public quality is based on using the professional quality in the 
public's service (Negri et al., 2009, p. 8).

As revealed by Victor (2007), in the case of museums and other cultural and artistic organisations, quality instruments have only been used for a short period and quality management is still not considered a priority. In general, museums experts are preoccupied by the "professional quality" of a museum, i.e. the structure, the conservation and the research of collections. However, in the last years more and more museums have shown their interest in offering quality services to their visitors. The reason for this is simple: since any purchase decision depends on price and quality (Ilieş, 2003), as long as they want to thrive on the highly competitive leisure and tourism market, museums must give a higher and higher attention to the various elements included in what their visitors perceive as quality services (Radder \& Han, 2013). Also, an important number of indicators used for measuring museum sustainability are based on museums' ability to attract visitors and adjust their offer so as to contribute at the same time both to tourist development of their respective regions and increase of social inclusion (Pop \& Borza, 2016).

In this context, the problem of the relationship between museum sustainability and quality arises. It is a well-known fact that for any increase in quality higher expenses are needed. This can be perceived as an economic disadvantage (Zima \& Sabou, 2010). On the other hand, visitors' loyalty comes from their satisfaction, which in its turn depends on the quality of the experience they are offered, from the moment they park their vehicles or decide to contact a museum by telephone up to the moment they exit the museum, having received the appropriate information or the leisure experience they desired (Rowley, 1999).

Therefore, in this competitive environment, for any museum that is striving for success and survival it is essential to provide quality services, products and experiences. These will lead to higher visitor satisfaction and loyalty, which will have a good impact on a museum's performance (Radder et al., 2011). On the one hand, a satisfied visitor is likely to return to the same museum; on the other hand, a satisfied visitor will recommend the respective museum to other people (Radder \& Han, 2013). By retaining its actual visitors and attracting new ones, a museum can earn higher incomes and a better market share. Consequently, the provision of quality services can ensure a competitive advantage and at the same time can help a museum better its sustainability (Maher et al., 2011).

Moreover, one of the sustainable development principles is to increase or at least to maintain the same quality living standard (Anghel et al., 2014). Thus, in order to be able to contribute to the sustainable development of the community it belongs to, a museum must be preoccupied with measuring and improving the quality of the services it provides to visitors. Museums, and implicitly the quality of the products and services they offer, play an important role in the sustainable development of tourism. According to Marković et al. (2013), "sustainability refers to the capacity of a destination of maintaining the quality of its physical, social, cultural and environmental resources while it is competing on the market." Since the museums' mission is to conserve cultural resources and contribute to the development of society, we can conclude that these institutions hold a significant role in the sustainable development of tourism, by means of the cultural and heritage tourism (Marković et al., 2013). By protecting the cultural heritage and by offering visiting experiences of it, museums facilitate the development of cultural tourism without 
endangering the heritage resources.

Hence, in order to fulfil their role in the sustainable development, it is not enough for museum to focus on increasing, conserving, researching and promoting the heritage (these are elements of the museum professional quality); they should as well satisfy their visitor's needs and expectations. Therefore, adjusting the museum's services to the consumers' needs, offering quality services and improving them permanently are important aspects of museum management in order to enhance sustainability (Marković et al., 2013). By providing quality services, museums do not only impact positively on people's lives, but can also earn benefits for themselves. Just like in the private sector, a museum can use service quality for the purpose of earning a competitive advantage and differentiating from its competitors (Maher et al., 2011), which in the end will lead to higher incomes and better sustainability.

\section{Methods}

The purpose of this research is to analyse the relation between quality and sustainability in museum sector and examine how quality can be used by museums so as to increase their sustainability and generate greater and better results for both people and society. The research hypotheses are:

$\mathrm{H}$ 1. There is a connection between quality and sustainability in museum sector;

H 2. Museums can increase their level of sustainability by using quality instruments;

H 3. Quality instruments are not very much used by Romanian museums.

To check the hypotheses, in the first stage we reviewed the existing research on quality management in museums. Subsequently, these hypotheses were tested as part of a more extensive research on museum management and sustainability carried out in the period 2014-2015. As a research instrument we used semi-structured interviews with 12 experts from the museum sector. These experts were selected based on their expertise, experience and availability. Nine experts occupy a leading position in museums or in the National Network of Romanian Museums. Another criterion of selection was the city. Thus, the 12 experts interviewed are from Bucharest, Cluj-Napoca and Baia Mare, and are currently working or worked formerly in museums of art, folk art, ethnography, history and archaeology. Once these interviews recorded and transcribed, the most important ideas expressed by the experts were synthesised. In order to assure the confidentiality of their answers, the experts are herein marked randomly with letters A to L. The theoretical and empirical results obtained from the two researches are detailed below.

\section{Results: quality in the experts' view}

The majority of the interviewed experts mentioned quality studies and indicators as a way of measuring a museum's sustainability. For example, expert E associates the sustainability of a museum with its capacity of attracting the required financial resources and at the same time assuring a high quality of its cultural products: "...such intelligent solutions of obtaining financing or projects should be found as to generate money for the museum while keeping an appropriate cultural quality." The same expert suggests that quantitative and 
qualitative indicators must be used as means for measuring a museum's sustainability. While as regards the quantitative indicators museums have all the information they need so as to be able to carry out their analysis, the situation is not the same when it comes to the qualitative indicators. As we can deduce from this expert's assertions, studies in the field of quality are a big problem for Romanian museums.

Expert A believes that sustainability should be measured firstly "taking into account the reaction of the community, of the public" (which is a qualitative indicator). However, the same expert says that total quality management is "a term known to many people, but less to the museum community". Expert B associates the sustainability of a museum with the degree to which that museum can satisfy the community needs. In this respect, expert B emphasises that a sociological research is needed in order to identify a community's cultural needs.

Expert $\mathrm{C}$ believes that, in order to improve their sustainability, museums should adjust their programmes according to the public's preferences: "for the public to enter a museum, it is the quality of the programmes that should be increased in the first place. As long as we offer quality programmes, the public will come to the museum. As long as we offer quality exbibitions, as long as we have, I don't know, quality concerts, the public will come to the museum." This expert also emphasises the gap between quality as it is perceived by museum employees and the quality looked for by visitors: "there is a dispute between the experts and those who are, for instance, the authors of such ideas, as many a time it is understood that these tastes of the public do not measure up to the scientific or artistic quality proposed by the museum. That is, that the public prefers how shall I put it? - more consumeristic activities, of a lesser quality, and so on." As regards the public's needs, this expert admits that these are rather little known. The research carried out by his museum aimed at defining the visitors' profile and identifying their preferences about the museum opening hours. Thus, although the visitors did complete questionnaires, the purpose of these questionnaires was not to identify the visitors' expectations or their level of satisfaction after visiting the museum.

Expert D also upholds the idea that sustainability should be measured based on a number of qualitative indicators. However, this expert's answers lead to the conclusion that a large number of museums draw their information on the quality perceived by their visitors only from the messages in the guestbooks. Therefore, although sustainability seems to be closely linked with quality, Romanian museums don't generally use any quality analysis and quality improvement instruments.

Expert F mentions that museums must adjust their offers so that the needs of the public are met: "Therefore, the idea is that the visiting public should receive within the museum as many types of services as possible. They should actually visit the exbibitions offered, that is practically the cultural component, but, if they want other types of services as well, such as the services offered by a restaurant, these should be included in the museum's offer."

Expert $G$ states that visitor statistics are the chief source of information based on which museums" sustainability is determined: "For the moment, except for visitor statistics, we do not have any other instrument that we can use to measure our sustainability." Expert $\mathrm{G}$ also says that one weakness of the museum he belongs to is that it can not rely on a study of its visitors' needs, the satisfaction they feel after they visit the museum and their opinions about the services offered by the museum. In his opinion the lack of such research results into a lack of certain exhibitions and programmes which would be attractive for 
the public.

The views of the other experts we interviewed are similar to those expressed by experts A-G. To sum up, although some museum experts consider that quality is very important in measuring and improving sustainability, most Romanian museums are not yet using quality management techniques and instruments. This conclusion also results from the fact that, out of the 397 museums currently existing in Romania (INS, 2015:12), only 75 were accredited as of October 7, 2015 (CIMEC, 2015). Of course, there are exceptions as well, chiefly among the big, national museums. Such an example is the "Dimitrie Gusti" National Village Museum which in the year 2012 implemented a quality management system according to the conditions set forth in the ISO 9001:2008 standard (for more details, see the museum's website, the sections "Certificates of excellence", at http://www.muzeul-satului.ro/certificate-de-excelenta).

In conclusion, quality enables organisations to achieve a better sustainability by improving its competitive position on the market. For this, museums must identify the factors that influence the quality and implement quality measuring systems upon which the permanent improvement processes can be based.

\section{Factors influencing museum quality}

The factors influencing museum quality can be grouped into three categories: factors determining museum quality from the clients'/visitors' point of view, from the staff's point of view, and factors that influence museum quality irrespective of the visitors' or staff's perception.

\subsection{Factors determining museum quality from the visitors' point of view}

Quality assessment from the visitors' point of view is directly linked with the visitors' satisfaction. In their study on the visitors' long-term satisfaction, Hasiao and Yao (2012) mention the following factors: the attitude of the staff within the service, the ticket prices, the operating strategies and the attractiveness as compared to the competitors (Hasiao \& Yao, 2012). Other authors consider that the quality of the visiting experience depends on three main factors: the exhibition, the staff and the facilities offered by the museum. From this point of view, the total quality offered by a museum is given by the quality of its products, the quality of its services and the quality of the visiting experience (Radder et al., 2011: 317).

Despite many voices which uphold this quality trilogy in museums (the quality of the products, the quality of the services and the quality of the experience), there are authors who consider that the experience during the visitation process and the psychological effect caused by the participation in an activity influence the quality perceived by the visitors to a much larger extent than the museum's services proper. This was explained by Hosany and Witham (Hosany and Witham, 2010:351, apud. Radder et al., 2011) through the fact that people are in search of ,unique, memorable and momentous experiences which will stimulate them intellectually, engage them personally and touch their hearts, providing them at the same time with feelings of delight". Given the fact that besides products and services, museums also offer experiences, the degree of subjectivity involved in quality assessment is even larger (Radder et al., 2011: 319) and in the end leads to different global 
experiences for each client (Rowley, 1999).

The dependence of museum quality on a series of subjective elements was also noted by Pachucki (2012), who, wondering whether people classify museums qualitatively in the same way, reached the conclusion that different people will compare organisations differently. The reasons for this is that the quality perceived by visitors is influenced by the comparisons they make and these comparisons, in their turn, depend on the visitors' previous experiences: ,visiting the Frick collection after you have visited the Met collection is a totally different thing than visiting the Frick collection after you have visited the Neue Gallery" (Pachucki, 2012). To sum up, we can assert that the visitors' perception of the quality of a museum depends on a series of objective and subjective factors (Pachucki, 2012), which makes the assessments of the quality from the consumers' point of view not identical. This makes any effort of assessing and improving the quality even more difficult.

\subsection{Factors determining museum quality from the staff's point of view}

From the point of view of museum staff, the professional holding various roles within the organisation use a different set of quality measuring criteria. Curators and museographers tend to regard quality as dependent only on the collections held by the museums and the way in which the collections are used (through scientific research and conservation). Public relation experts and museum educational experts regard quality as dependent on the educational programmes carried out, the quality of the human resources, the attention given to the public, the facilities offered, the visitors' experience, the accessibility and the reputation of the museum. The ones who generally have an integrative view on quality are the managers, who consider that museum quality is based "not only on what a museum has, but also on what it does and how well it does it" (Pachucki, 2012). In other words, the quality criteria considered by managers can include the acquisitions, the exhibitions, the public programmes and the general access of the community to the museum.

Pachucki's study (2012) reveals that from the museum staff's point of view consumer satisfaction holds only the third place in the global museum quality assessment, which indicates that (1) on the one hand, changes are on the way in the behaviour and attitude adopted by museums on the market, and (2) on the other hand, such changes are just incipient and further substantial efforts are needed so that museums can adjust completely to the competitive environment they operate in.

\subsection{Factors influencing museum quality irrespective of the visitors' or the staffs' perception}

The third category of factors that influence museum quality includes the museum's organizational size and its financial resources. Therefore, the bigger the budget of a museum, the bigger the funds invested in technological and digital applications. Also, a big budget allows a museum to increase its staff costs and hire more and better trained experts. The technological investments and the specialised human resources will result into better services provided, an increased long-term visitor satisfaction, visitor loyalty and potential consumers' increased intentions of visiting the museum. This leads to a higher number of visitors and higher income earned by the museum from selling tickets, which will make the government more eager to subsidise the museum in the next 
year, thus creating a positive loop (Fig. 1). The risk associated to this process is that it can temporarily affect the quality of services (a higher number of visitors can lead to overcrowding) until a state of balance is attained (Hasiao \& Yao, 2012).

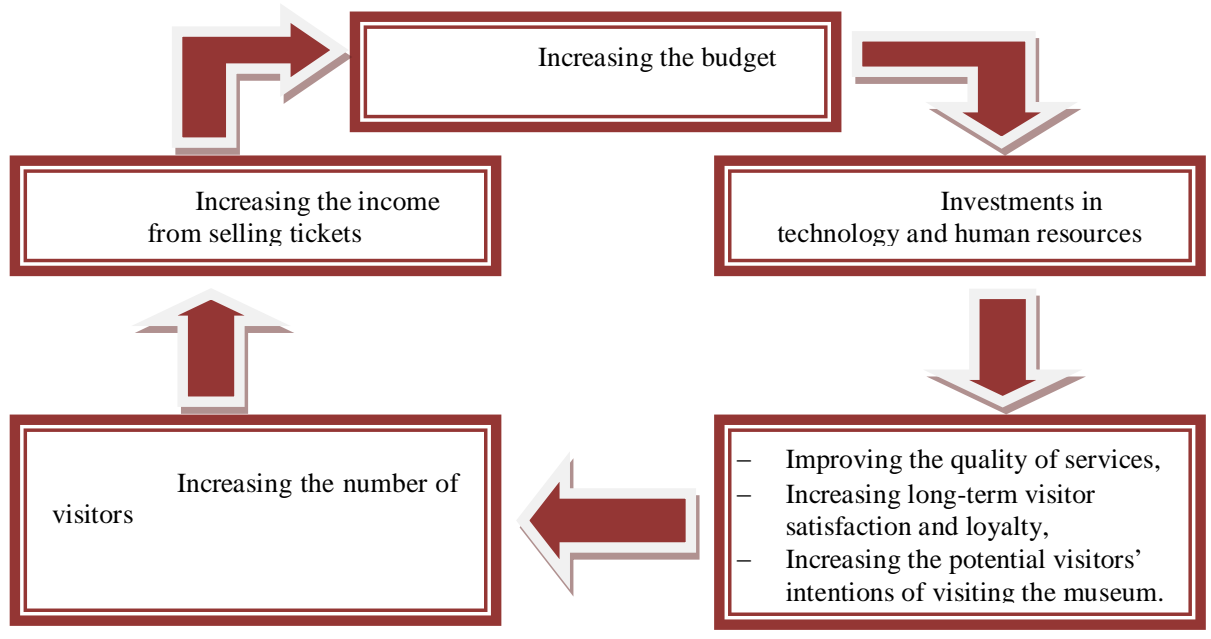

Fig. 1 - Loop of museum quality improvement based on a bigher budget

Source: adapted after (Hasiao \& Yao, 2012)

Therefore, the implementation of a quality management system and the permanent improvement of an organisation can require significant financial means (Victor, 2007). However, given the benefits that can be obtained as a result of the permanent improvement, quality can be regarded as an investment which will pay off in time as the organisation's long-term sustainability increases. The high costs do not exclude the possibility of using certain instruments, which are specific for each programme or quality management model, respectively the adaptation of a realistic solution to individual situations, based on the available human and economic resources. The actions that can be carried out step by step, without engaging into a total quality management programme as a whole, are as follows (Negri et al., 2009):

$>\quad$ Displaying a table with the services offered (communicating the organisation's mission, transparency in its relationship with it users),

Defining performance indicators and the criteria accepted for measuring the museum's performance,

$>\quad$ Conducting a systematic research on the visitor and user profile,

$>\quad$ Conducting a qualitative and quantitative research on consumer satisfaction (through questionnaires, focus-groups and other methods),

$>\quad$ Conducting a research on the staff satisfaction,

$>\quad$ Adopting a self-assessment system,

$>\quad$ Adopting a protocol of corrective actions required for solving critical situations and removing weaknesses,

Publishing an annual report as a social responsibility instrument.

Starting from these quality influencing factors grouped into three categories, museum 
managers can elaborate and implement quality control systems, which will allow service improvement and a better fulfilment of the museum's mission and objectives. Below are presented the various views described in the literature on the assessment of the quality of a museum.

\section{Measuring museum quality \\ 5.1 The SERVQUAL model}

The SERVQUAL model measures the quality of services by comparing the clients' expectations with their perceptions of service performance. This model uses 22 questions through which clients' expectations and perceptions are measured. The five dimensions of this model are as follows (Misiura, 2005):

- Tangibility, which refers to the aspect of the physical facilities, the equipment, the staff and the means of communication which together compose what the visitor or client actually sees;

- Reliability, which measures the extent to which an organisation can fulfil the promises made to its clients in what regards the quality of its services, both as concerns the reliability and the accuracy of such services;

- Responsiveness, which refers to offering prompt services and how far an organisation is willing to go so as to serve a client;

- Assurance, which is determined by the knowledge and complaisance of the staff and their capacity of inspiring confidence and safety.

- Empathy, which refers to the individual care and attention given by the organisation and its staff to the consumers.

Throughout the years, the SERVQUAL model has become the instrument that is most often used for measuring the service quality and for the elaboration of quality improving strategies. However, criticism was expressed in connection with the application of the SERVQUAL model in the non-profit sector due to the asymmetry between its tangible and its functional dimensions (Maher et al., 2011). Except for one single dimension which describes the tangible elements of the service, all the others measure the functional interaction between the clients and the staff.

This underestimation of the tangible elements can be explained through the fact that SERVQUAL was created for services where the clients tend to have just a superficial knowledge of the tangibles (e.g., the financial services) (Radder \& Han, 2013). Trying to overcome the weaknesses of this instrument, some researchers opted for adjusting the SERVQUAL scale to the individual particularities of various museums. Thus, in order to carry out research on a children's museum, Maher et al. (2011) detailed the fifth dimension of the SERVQUAL scale as: (1) staff's empathy, and (2) organisational empathy. Also, the authors included two elements which refer to the museum staff's knowledge and the staff's ability to operate the exhibits. The reason for this was that interactivity is one of the main attractions of children's museums. The components of the SERVQUAL scale proposed for this type of museums are shown in Table 1. 
Table 1 - The SERVQUAL scale adjusted to the individual features of children's museums, Source: (Maher et al., 2011)

\begin{tabular}{|c|c|c|}
\hline lity & & $S$ \\
\hline 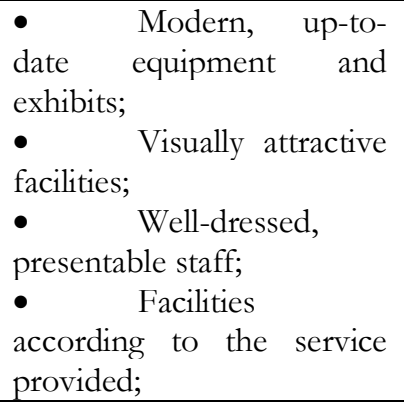 & $\begin{array}{l}\text { - The promised deliveries } \\
\text { are met in due time; } \\
\text { - } \quad \text { Offering } \\
\text { services; } \\
\text { - Keeping accurate } \\
\text { records; } \\
\text { - Informing the visitors } \\
\text { about when the services will be } \\
\text { provided; }\end{array}$ & $\begin{array}{l}\text { - The visitors receive } \\
\text { prompt services; } \\
\text { - The staff are willing } \\
\text { to assist the visitors; } \\
\text { - The staff are not too } \\
\text { busy to answer the visitors' } \\
\text { requests; }\end{array}$ \\
\hline Assurance & Slan S EMT & Organisational en \\
\hline $\begin{array}{l}\text { - The visitors can } \\
\text { trust the staff of the } \\
\text { museum; } \\
\text { - The visitors feel } \\
\text { safe while visiting the } \\
\text { museum; } \\
\text { - The staff are polite; }\end{array}$ & $\begin{array}{l}\text { - The staff give the } \\
\text { visitors individualised attention; } \\
\text { - The staff give visitors } \\
\text { personal attention; } \\
\text { - The staff know the } \\
\text { visitor's needs; }\end{array}$ & $\begin{array}{l}\text { - The museum is } \\
\text { preoccupied with the visitors' } \\
\text { best interests; } \\
\text { - The opening hours } \\
\text { are reasonable; } \\
\text { - The staff should have } \\
\text { extensive knowledge about the } \\
\text { exhibits; } \\
\text { - } \quad \text { The staff should } \\
\text { know how to use the exhibits. }\end{array}$ \\
\hline
\end{tabular}

Therefore, despite the contradictory opinions on the application of SERVQUAL to measure quality in public and non-profit sectors, the adaptation of this instrument to the individual features of each cultural organisation contributes to guiding the process of strategic decisions as regards the permanent improvement of service quality (Maher et al., 2011).

\subsection{The HISTOQUAL model}

The controversies aroused by the application of the SERVQUAL model and the necessity of adjusting this model to the features of the various types of organisations led to the creation of the HISTOQUAL model.

This model approaches particularly the quality of the services provided by historic/memorial houses and therefore is more suitable for museums. The HISTOQUAL model includes all the elements of the SERVQUAL model plus the following: (1) an examination of communication, for example how the potential consumers are informed about the product offer and, when they are in the museum, how they should be guided in the exhibiting spaces (the use of signs, information materials, etc.), and (2) the consumables, such as catering facilities, cafés, shopping areas, etc. (Misiura, 2005). Thus, the HISTOQUAL model includes 24 items, grouped into five dimensions as well, but these are slightly different from the ones in the initial model: prompt 
reaction, tangibility, communication, consumables and empathy. The prompt reaction is about how efficient the staff is and how well they can identify the clients' needs. Tangibility refers to the physical environment of the museum (inside and outside) and includes criteria such as cleanliness, authenticity and attractivity. Communication assesses the quality and quantity of information that is supplied. Consumables includes the extra services provided, such as restaurants and shops. Empathy is defined as the willingness to take into account the needs of children and those of disabled visitors (Marković et al., 2013).

Although the HISTOQUAL model is built taking into account the characteristics of the services provided by memorial houses, Marković et al. (2013) adjusted it so that it fits better the particularities of museums. The reliability analysis carried out by these authors reveals that the altered HISTOQUAL scale is extremely reliable and represents a valuable and trustworthy instrument for measuring the expectations and the perceptions of the quality of the services provided in the museum sector (Marković et al., 2013). The attributes of the museum services in the altered HISTOQUAL scale are detailed in Table 2.

Table 2 - The altered HISTOQUAL scale for measuring quality in museums. Source: (Marković et al., 2013)

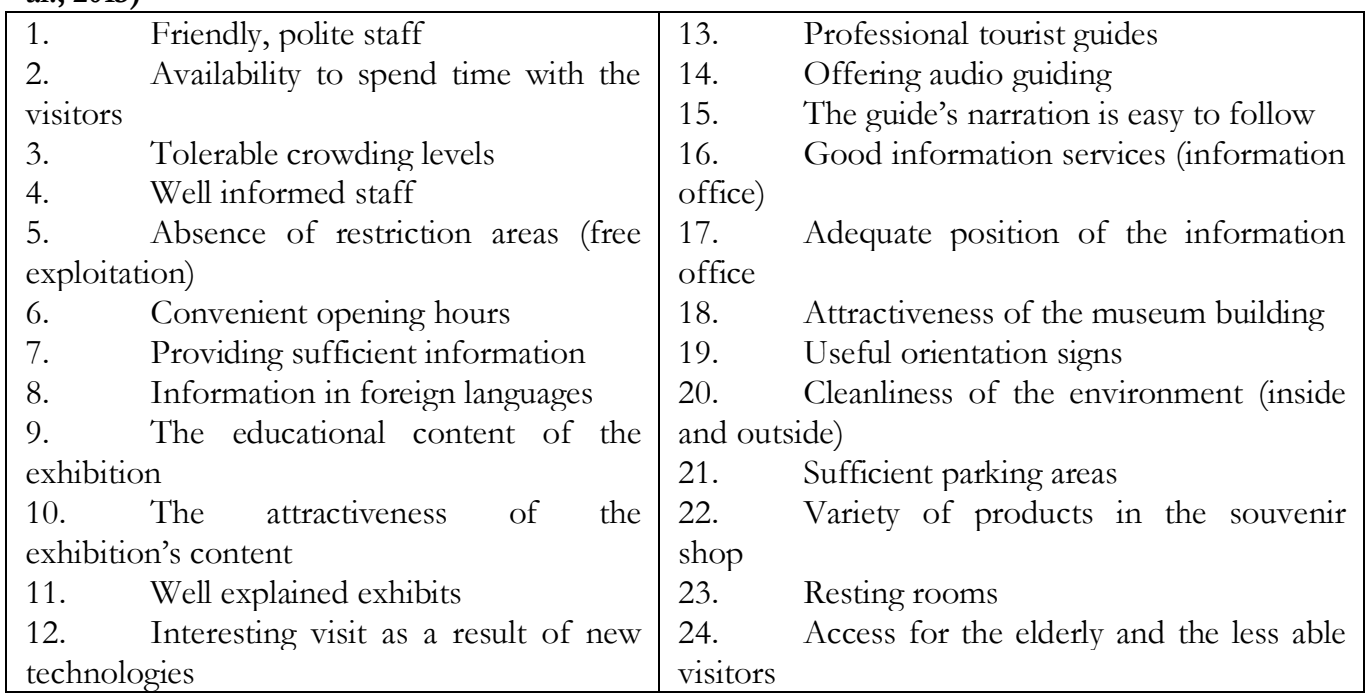

\section{Conclusion}

Having reviewed the literature, we concluded that museum quality is dependent on the quality of the products, services and experiences each museum offers. While traditionally museums were preoccupied only with the quality of their heritage, not the quality of the experiences they offered to their visitors, the interviews with the 12 museum experts revealed that things are beginning to slowly change. Currently, in Romania there are few museums which have implemented a quality management system. However, the interviewed experts believe that museum sustainability does not rely solely 
on the care for its heritage and keeping the museum collections in optimum conditions, but also on museums adjusting and diversifying their offers so that the visitors' satisfaction is as high as possible. Therefore, these experts consider "the public quality" of museums as important as "the professional quality" and say that both types of quality are needed for a museum to become sustainable. Still, we must note the dependence of the public quality on the professional quality. As long as the collections of a museum are not well maintained and the museum experts are not able to offer information about the exhibits, visitors can not enjoy a quality experience in a museum.

The new trend of regarding museum quality as dependent on both the heritage and the services provided is an important step forward towards the adaptation of museums to the requirements of the competitive environment, where the attention towards the clients is the priority. As regards the relationship between quality and sustainability, we can conclude that any improvement in the quality impacts positively on the cultural and social sustainability of museums. At the beginning the increase in quality generates a series of costs which have an impact of the economic sustainability. However, on the long term these costs will be exceeded by the higher income generated as a result of a bigger number of visitors.

In order to become sustainable, and consequently cope with the challenges of their environment, museums must strive permanently to improve the quality of the products, services and experiences they offer to their visitors. Taking into account the social component of sustainability, as well as the fact that quality is directly linked to consumer satisfaction, we can conclude that any process of assessing the sustainability of a museum must include, among others, a measurement of the quality of the products, services and experiences the respective museum offers. In this respect the measuring instruments developed by researchers, such as SERVQUAL and HISTOQUAL are particularly useful.

\section{References}

Anghel, C., Vele, C. L., Toader, R., Radulescu, C., \& Toader, C. (2014). The implementation of a strategy for local sustainable development. Managerial Challenges of the Contemporary Society. Proceedings, 7(1), 160.

CIMEC, (2015). Lista muzeelor acreditate până la data de 07.10.2015. Retrieved April 9, 2016, from http://ghidulmuzeelor.cimec.ro/Muzee-acreditate-reacreditate-07-10-2015.pdf.

Hosany, S. \& Witham, M. (2010). Dimensions of cruisers' experiences, satisfaction, and intention to recommend. Journal of Travel Research, 49(3), 351-364.

Hsiao, C.H., Yao, M.H., (2012). System Dynamics Approach to Visitors' Long-Term Satisfaction with Museum: A Case Study of The National Museum of Natural Science. International Journal of Electronic Business Management, 10(2),113-121;

Ilieş, L., (2003), Managementul calității totale. Cluj-Napoca: Editura Dacia;

INS, (2015). Activitatea unităților cultural - artistice anul 2014, ISSN: 2066-4087. Retrieved April 9, 2016, from bttp:// wmw.insse.ro/ cms/files/publicatii/publicatii\%20 statistice\%20operative/34. Activitat ea\%20unitatilor $\% 20$ cultural-artistice $\% 20 \mathrm{in} \% 20$ anul\%202014.pdf.

Jackson, R. (1988). A museum cost function. Journal of Cultural Economics, 12(1), 41-50.

Maher, J.K., Clark, J., Motley, D.G., (2011). Measuring Museum Service Quality in Relationship to Visitor Membership: The Case of a Children's Museum, Marketing Management, 13(2), 29-42.

Marković, S., Raspor, S., Komšic, J., (2013). Museum Service Quality Measurement Using the Histoqual Model. Tourism in Southern and Eastern Europe, pp. 201-216;

Misiura, S., (2005). Heritage Marketing. London: Routledge. 
Negri, M., Niccolucci, F., Sani, M., (2009). Quality in museums. Budapest: Archaeolingua.

Pachucki, M.C., (2012). Classifying quality: Cognition, interaction, and status appraisal of art museums. Poetics, 40, 67-90.

Pop I.L., Borza A., (2016). Factors Influencing Museum Sustainability and Indicators for Museum Sustainability Measurement. Sustainability, 8(1), 101.

Radder, L., Han, X., (2013). Perceived Quality, Visitor Satisfaction and Conative Loyalty in South African Heritage Museums. International Business \& Economics Research Journal, 12(10), 1261-1272;

Radder, L., Han, X., Hou, Y. (2011). An integrated evaluation of the heritage museum visit: a disconfirmation approach. International Journal of Management Cases, 13(3), 315-326.

Rowley, J., (1999). Measuring total customer experience in museums. International Journal of Contemporary Hospitality Management, 11(6), 303-308.

Victor, I., (2007). Museums and quality, from the concept of the museum that carries out functions to the museum that provides services. Cadernos de Sociomuseologia, 27, 45-61.

Zima, L., Sabou, S. (2010). Quality and the consumer. Studia Universitatis "Vasile Goldiș" Arad, Seria Siintse Economice, 20, part III, 56-63. 